Louisiana State University

LSU Digital Commons

Faculty Publications

Department of Chemistry

$1-14-2011$

\title{
Changing the culture of science education at research universities
}

\author{
W. A. Anderson \\ Howard University \\ U. Banerjee \\ University of California, Los Angeles \\ C. L. Drennan \\ Massachusetts Institute of Technology \\ S. C.R. Elgin \\ Washington University in St. Louis \\ I. R. Epstein \\ Brandeis University
}

See next page for additional authors

Follow this and additional works at: https://digitalcommons.Isu.edu/chemistry_pubs

\section{Recommended Citation}

Anderson, W., Banerjee, U., Drennan, C., Elgin, S., Epstein, I., Handelsman, J., Hatfull, G., Losick, R., O'Dowd, D., Olivera, B., Strobel, S., Walker, G., \& Warner, I. (2011). Changing the culture of science education at research universities. Science, 331 (6014), 152-153. https://doi.org/10.1126/science.1198280

This Article is brought to you for free and open access by the Department of Chemistry at LSU Digital Commons. It has been accepted for inclusion in Faculty Publications by an authorized administrator of LSU Digital Commons.

For more information, please contact ir@lsu.edu. 


\section{Authors}

W. A. Anderson, U. Banerjee, C. L. Drennan, S. C.R. Elgin, I. R. Epstein, J. Handelsman, G. F. Hatfull, R. Losick, D. K. O'Dowd, B. M. Olivera, S. A. Strobel, G. C. Walker, and I. M. Warner 
Washington University in St. Louis

Washington University Open Scholarship

Biology Faculty Publications \& Presentations

Biology

$1-2011$

\section{Changing the culture of science education at research universities}

W. Anderson

U Banerjee

C Drennan

Sarah C.R. Elgin

Washington University in St. Louis, selgin@wustl.edu

I Epstein

See next page for additional authors

Follow this and additional works at: https://openscholarship.wustl.edu/bio_facpubs

Part of the Biology Commons

\section{Recommended Citation}

Anderson, W.; Banerjee, U; Drennan, C; Elgin, Sarah C.R.; Epstein, I; Handelsman, J; Hatfull, G; Losick, R; O'Dowd, D; Olivera, B; Strobel, S; Walker, G; and Warner, I, "Changing the culture of science education at research universities" (2011). Biology Faculty Publications \& Presentations. 189.

https://openscholarship.wustl.edu/bio_facpubs/189

This Article is brought to you for free and open access by the Biology at Washington University Open Scholarship. It has been accepted for inclusion in Biology Faculty Publications \& Presentations by an authorized administrator of Washington University Open Scholarship. For more information, please contact digital@wumail.wustl.edu. 


\section{Authors}

W. Anderson, U Banerjee, C Drennan, Sarah C.R. Elgin, I Epstein, J Handelsman, G Hatfull, R Losick, D O'Dowd, B Olivera, S Strobel, G Walker, and I Warner 


\section{Changing the Culture of Science Education at Research Universities}

\author{
W. A. Anderson, ${ }^{1}$ U. Banerjee, ${ }^{2}$ C. L. Drennan, ${ }^{3}$ S. C. R. Elgin, ${ }^{4}$ I. R. Epstein ${ }^{5}$, J. Handelsman, ${ }^{6}$ G. \\ F. Hatfull, ${ }^{7}$ R. Losick, ${ }^{8 *}$ D. K. O'Dowd ${ }^{9 *}$ B. M. Olivera, ${ }^{10}$ S. A. Strobel, ${ }^{6}$ G. C. Walker, ${ }^{3}$ I. M. Warner ${ }^{11}$
}

$\mathrm{P}$ rofessors have two primary charges: generate new knowledge and educate students. The reward systems at research universities heavily weight efforts of many professors toward research at the expense of teaching, particularly in disciplines supported extensively by extramural funding (1). Although education and lifelong learning skills are of utmost importance in our rapidly changing, technologically dependent world (2), teaching responsibilities in many STEM (science, technology, engineering, and math) disciplines have long had the derogatory label "teaching load" $(3,4)$. Some institutions even award professors "teaching release" as an acknowledgment of their research accomplishments and success at raising outside research funds.

Some studies suggest little or no correlation between effective teaching, judged by student evaluations, and research, as measured by productivity and citations (5). But we contend that excellence in research and teaching need not be mutually exclusive but are instead intertwined and can interact synergistically to increase the effectiveness of both. The distinction between research and teaching is somewhat artificial; professors teach students how to learn from known sources in the classroom, but also how to create new knowledge in their research laboratories.

We are Howard Hughes Medical Institute (HHMI) professors, biomedical research scientists who receive support from HHMI for creating new programs that more effectively engage students in learning science. We represent a diversity of institutions, from wellendowed private universities to large and underfunded state universities. In our opinion, science education should not only provide broad content knowledge but also develop analytical thinking skills, offer understanding of the scientific research process, inspire curiosity, and be accessible to a diverse range of students. We should be preparing students for a lifetime of learning about science with

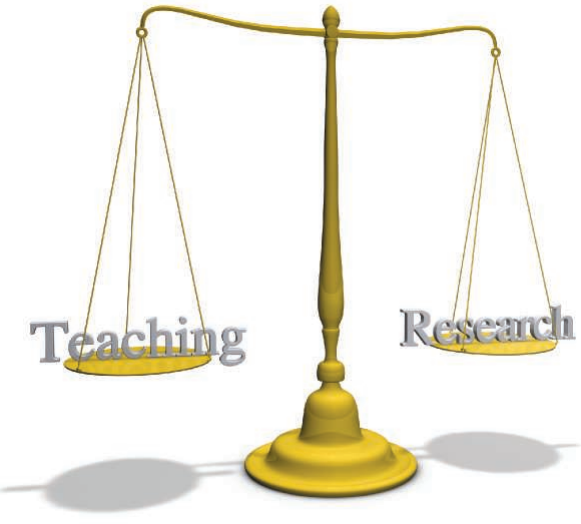

an understanding of its power and limitations. Evidence shows that approaches that accomplish these goals include active, engaging techniques; inquiry-based approaches; and research courses $(6)$.

All of us have experienced the challenges of balancing teaching and research. Our ability to invest time and effort into improving undergraduate science education has been facilitated by extramural support and outside recognition provided by HHMI. How do we now help transform our research universities so that the teaching of science and scientific research are seen more broadly as equally valuable and mutually reinforcing?

Departmental and university cultures often do not adequately value, support, and reward effective pedagogy. Outstanding contributions to research are evaluated by standard measures (e.g., publications and grant support); are recognized globally as well as locally; and are rewarded within the university (e.g., with promotions or salary increases). Teaching, in contrast, is rarely judged and appreciated from the outside and often only minimally from within $(7,8)$. To establish an academic culture that encourages science faculty to be equally committed to their teaching and research missions, universities must more broadly and effectively recognize, reward, and support the

${ }^{1}$ Howard University, Washington, DC 20059, USA. ² University of California, Los Angeles, Los Angeles, CA 90095, USA ${ }^{3}$ Massachusetts Institute of Technology, Cambridge, MA 02139, USA. ${ }^{4}$ Washington University, St. Louis, MO 63130, USA. ${ }^{5}$ Brandeis University, Waltham, MA 02453, USA. ${ }^{6}$ Yale University, New Haven, CT 06520, USA. ${ }^{7}$ University of Pittsburgh Pittsburgh, PA 15260, USA. ${ }^{8}$ Harvard University, Cambridge, MA 02138,USA. 'University of California, Irvine, Irvine, CA 92697, USA. ${ }^{10}$ University of Utah, Salt Lake City, UT 84112, USA. ${ }^{11}$ Lousiana State University, Baton Rouge, LA 70803, USA

*To whom correspondence should be addressed. E-mail: losick@mcb.harvard.edu or dkodowd@uci.edu

Universities must better recognize, reward, and support the efforts of researchers who are also excellent and dedicated teachers.

efforts of researchers who are also excellent and dedicated teachers.

Toward this end, we advocate seven initiatives (reflecting our views and not necessarily those of HHMI). Although many of these ideas are not new, the context in higher education has changed because of widespread concern about educating enough scientists and scientifically literate citizens (9) and because resources that enable change have improved markedly in recent years (10-12).

1. Educate faculty about research on learning. No scientist would engage in research without exploring previous work in the field, yet few university educators read education research. Universities can demonstrate that they value teaching by treating it as a scholarly activity, such as through faculty training in teaching that is predicated on evidence-based $(10,13)$ approaches. Training should address education theory, tested practices, and methods to assess learning. Teachers should have time to experiment with new methods, identify strategies that they can implement effectively in specific settings, and take advantage of resources that enable translation of learning principles to teaching practice. These practices must include strategies to engage students in introductory courses, arguably the highest-impact change that could be made $(10,13-15)$

2. Create awards and named professorships that provide research support for outstanding teachers. Many universities recognize outstanding teachers with a special title or a modest monetary award. Campus-wide recognition should also include unrestricted funds, as is typical for named professorships, which make it feasible to sustain research activities while continuing to contribute to teaching excellence. Incorporating talks by these individuals into distinguished science lecture series is an opportunity to introduce innovative pedagogy. This may also attract a new donor population interested in sponsoring named professorships for faculty who have demonstrated excellence in the training of future scientists. In addition to campuswide recognition, annual department-level awards for excellence in teaching could provide funds, allocated by the dean, to support 
the scholarly activities of the recipient. This would not only help more faculty who have devoted significant effort to teaching maintain their research programs but also demonstrate to their colleagues that the effort required to achieve teaching excellence is valued. Named lecture series could bring professors from other universities who are distinguished as both research scientists and teachers to deliver a campus-wide lecture on pedagogy and a discipline-specific lecture on their research.

3. Require excellence in teaching for promotion. Formal criteria for tenure and promotion typically indicate that teaching and scholarship carry equal weight. The reality, however, is that most research-oriented universities promote faculty primarily on the basis of research achievements and ability to raise money from sources outside the university. Promotion that requires excellence in teaching would go a long way toward improving education. We need to reach agreement on broad goals of college science education and establish a rubric for evaluating the extent to which teachers are meeting these goals. We must identify the full range of teaching skills and strategies that might be used, describe best practices in the evaluation of teaching effectiveness $(16,17)$ (particularly approaches that encourage rather than stifle diversity), and define how these might be used and prioritized during the promotion process.

4. Create teaching discussion groups. Teaching is often conducted out of sight of departmental colleagues. Even in large introductory classes that are taught by teams of instructors, members of the team are often absent from each other's presentations. To address this, both junior and senior faculty members should be brought together in small, peer teaching groups. Group members would attend each other's lectures and provide confidential critiques that highlight the most effective or innovative teaching strategies used and identify steps to increase effectiveness. Such peer support demonstrates that the department values, and shares responsibility for, good teaching. Group members are exposed to a variety of teaching strategies, some of which may positively affect their own practices. Annual meetings of the faculty at large, hosted by the dean, should routinely include discussion of innovative teaching strategies.

5. Create cross-disciplinary programs in college-level learning. Researchers are often left to fend for themselves in attempting to learn and implement best teaching practices and in evaluating how well students learn.
Yet many research universities have unexploited resources that could be drawn upon to improve college-level learning. For example, many universities have Departments or Schools of Education, but only a few of those [e.g., $(18,19)]$ include in their mission undergraduate-level learning or robust connections to, and collaborations with, faculty members in STEM departments. Such collaborations could spawn innovative programs for experimentation and evaluation of teaching practices in the sciences. Psychology Departments often have experts in cognitive science who would be valuable participants in such programs. Though extensive discussion of best teaching practices is beyond the scope of this piece, we refer readers, e.g., to $(10,13,20-23)$, as well as the Supporting Online Material.

6. Provide ongoing support for effective science teaching. The National Academies Summer Institute has helped faculty from almost 100 research universities implement principles of scientific teaching (24). University-based teaching centers provide professional support to faculty for assessment across disciplines, as well as training teaching assistants. Some STEM programs explicitly include in their mission the support and improvement of STEM education [e.g., (25, 26)]. There is no better way to teach science than to engage students in doing science (2729). To provide such opportunities for large numbers of students demands ingenuity, a willingness to seek out and support mentors, and provision of lab and field facilities. Projects that can draw on student peer-mentoring deserve special attention as benefiting both mentor and mentee.

7. Engage chairs, deans, and presidents. The critical ingredient in creating a culture that values and promotes both teaching and science is leadership. Chairs of STEM departments, deans of schools, and presidents of universities must elevate the status of the teacherscientist, communicate the importance they attach to effective teaching, and create and support programs that promote innovation in science education [e.g., (30)].

The issues we raise go beyond the sciences. Increasingly, it seems that parents, funders of higher education, and others are questioning the value of the education that research universities provide. The continued vitality of research universities requires that we foster a culture in which teaching and research are no longer seen as being in competition, but as mutually beneficial activities that support two equally important enterprises: generation of new knowledge and education of our students.
References and Notes

1. V. Savkar, J. Lokere, Time to Decide: The Ambivalence of the World of Science Toward Education (Nature Education, Cambridge, MA, 2010); http://bit.ly/blWaPr.

2. J. B. Labov, A. H. Reid, K. R. Yamamoto, CBE Life Sci. Educ. 9, 10 (2010).

3. A. L. Johnson, J. Chem. Educ. 8, 115 (1931).

4. L. V. Koos, The Adjustment of Teaching Load in a University (Government Printing Office, Washington, DC, 1919); www.archive.org/details/adjustmentofteac00koosuoft.

5. H. W. Marsh, J. Hattie, J. Higher Educ. 73, 603 (2002).

6. R. A. Duschl, H. A. Schweingruber, A. W. Shouse, Eds., Taking Science to School: Learning and Teaching Science in Grades K-8 (National Academies Press, Washington, DC, 2007).

7. R. Wilson, Chron. High. Educ. 57(3), A1 (2010); http://chronicle.com/article/Why-Teaching-Is-NotPriority/124301/.

8. M. C. Taylor, Chron. High. Educ. 56(42), A22 (2010); http:// chronicle.com/article/An-Academy-to-Support/123779/.

9. Committee on Prospering in the Global Economy of the 21st Century et al., Rising Above the Gathering Storm: Energizing and Employing America for a Brighter Economic Future (National Academies Press, Washington, DC, 2007).

10. ]. Handelsman, S. Miller, C. Pfund, Scientific Teaching (Freeman, New York, 2007).

11. Education Resources Information Center, www.eric.ed.gov/.

12. Multimedia Educational Resource for Learning Online, www.merlot.org/merlot/index.htm.

13. W. B. Wood, Annu. Rev. Cell Dev. Biol. 25, 93 (2009).

14. J. Fairweather, Linking Evidence and Promising Practices in Science, Technology, Engineering, and Mathematics (STEM) Undergraduate Education: A Status Report for The National Academies National Research Council Board of Science Education (BOSE) (BOSE, Washington, DC, 2010); www7. nationalacademies.org/bose/Fairweather_CommissionedPaper.pdf.

15. N. Lasry, E. Mazur, ]. Watkins, Am. J. Phys. 76, 1066 (2008).

16. R. B. Barr, J. Tagg, Change 27, 13 (1995); http://ilte.ius.edu/pdf/BarrTagg.pdf.

17. M. W. Klymkowsky, K. Garvin-Doxas, M. Zeilik, Cell Biol. Educ. 2, 155 (2003)

18. University of Maryland Physics Education Research Group, www.physics.umd.edu/perg/.

19. Physics Education Research at Colorado UniversityBoulder, www.colorado.edu/physics/Educationlssues/.

20. D. Bok, Our Underachieving Colleges: A Candid Look at How Much Students Learn and Why They Should Be Learning More (Princeton Univ. Press, Princeton, N], 2005).

21. R. R. Hake, Latin Am. J. Phys. Edu. 1, 24 (2007).

22. M. A. McDaniel, A. A. Callender, in Learning and Memory: A Comprehensive Reference, ]. Byrne et al., Eds. (Elsevier, Oxford, 2008).

23. H. Pashler et al., Organizing Instruction and Study to Improve Student Learning (NCER 2007-2004, National Center for Education Research, U.S. Department of Education, Washington, DC, 2007).

24. C. Pfund et al., Science 324, 470 (2009).

25. STEM at North Carolina State University, http://stem.ncsu.edu/.

26. College of Engineering, https://engineering.purdue.edu/ Engr/Academics/Schools.

27. R. Taraban, R. L. Blanton, Eds., Creating Effective Undergraduate Research Programs in Science (Teachers College Press, New York, 2008).

28. E. Seymour, A.-B. Hunter, S. L. Laursen, T. DeAntoni, Sci. Educ. 88, 493 (2004).

29. D. Lopatto, Cell Biol. Educ. 3, 270 (2004).

30. C. Wieman, K. Perkins, S. Gilbert, Change (March-April 2010).

Supporting Online Material www.sciencemag.org/cgi/content/full/331/16014/152/ DC1

10.1126/science. 1198280 


\section{Science}

\section{Changing the Culture of Science Education at Research Universities}

W. A. Anderson, U. Banerjee, C. L. Drennan, S. C. R. Elgin, I. R. Epstein, J. Handelsman, G. F. Hatfull, R. Losick, D. K. O'Dowd, B. M. Olivera, S. A. Strobel, G. C. Walker and I. M. Warner

Science 331 (6014), 152-153

DOI: $10.1126 /$ science. 1198280

ARTICLE TOOLS

SUPPLEMENTARY

MATERIALS

RELATED

REFERENCES

PERMISSIONS http://science.sciencemag.org/content/331/6014/152

http://science.sciencemag.org/content/suppl/2011/01/13/331.6014.152.DC1

http://science.sciencemag.org/content/sci/331/6017/532.1.full http://science.sciencemag.org/content/sci/331/6020/1010.3.full http://science.sciencemag.org/content/sci/331/6019/858.1.full

This article cites 13 articles, 1 of which you can access for free http://science.sciencemag.org/content/331/6014/152\#BIBL

http://www.sciencemag.org/help/reprints-and-permissions

Use of this article is subject to the Terms of Service

Science (print ISSN 0036-8075; online ISSN 1095-9203) is published by the American Association for the Advancement of Science, 1200 New York Avenue NW, Washington, DC 20005. The title Science is a registered trademark of AAAS.

Copyright (C) 2011, American Association for the Advancement of Science 